\title{
Eksplorasi Kemanfaatan Field Study Bagi Peningkatan Kompetensi Mahasiswa (Studi Kasus pada Mahasiswa Fakultas Ekonomi Universitas Samudra)
}

\author{
Syardiansah \\ Prodi Manajemen Fakultas Ekonomi Universitas Samudra \\ e-mail:syardiansah@unsam.ac.id
}

\begin{abstract}
Abstrak
Pengembangan sumber daya manusia bertujuan untuk menghasilkan kerangka kerja yang logis dan menyeluruh terkait pengembangan lingkungan dimana sumber daya manusia dalam hal ini didorong agar belajar untuk tumbuh. Pengembangan sumber daya manusia merupakan upaya terus menerus untuk meningkatkan kualitas sumber daya manusia secara luas, melalui pendidikan (pembelajaran), pelatihan, dan pembinaan. Salah satu cara untuk mengembangkan sumber daya manusia adalah melalui pendidikan atau pembelajaran yang langsung diterapkan di lapangan dalam bentuk field study. Berdasarkan pengolahan dan analisis data, ditemukan bahwa field study memiliki manfaat yang baik untuk meningkatkan kompetensi mahasiswa. Manfaat yang didapat mahasiswa tersebut dalam bentuk informasi baru atau terkini, dapat melihat dunia kerja secara langsung, peningkatan pengalaman dan dapat membandingkan teori yang diperoleh di kelas dengan yang ada di lapangan. Sedangkan peningkatan kompetensi mahasiswa dari kunjungan belajar dalam bentuk peningkatan pengetahuan dan wawasan tentang dunia kerja, dan mahasiswa menjadi lebih kritis terhadap lingkungan sekitar.
\end{abstract}

Kata kunci: Field study, kompetensi mahasiswa.

\section{PENDAHULUAN}

Pengalaman belajar lapangan adalah satu bentuk cara pengajaran pada mahasiswa, disamping pengalaman belajar ceramah, pengalaman belajar praktik dan pengalaman belajar diskusi. Rangkaian berbagai bentuk pengalaman belajar harus memungkinkan dapat ditumbuhkan dan dibinanya sikap dan kemampuan pada peserta didik, sesuai tujuan pendidikan yang dirumuskan. Belajar bukan hanya dilakukan didalam kelas ataupun hanya membaca buku-buku literatur yang tersedia, namun kenyataannya saat ini ada beberapa mata pelajaran tertentu yang mengharuskan mahasiswa mengenal langsung objek yang sedang dipelajari.

Field study adalah aktivitas ataupun proses pembelajaran dengan langsung melihat kondisi lingkungan sekitar yang akan diamati sehingga memberikan keleluasaan yang lebih bagi peserta didik terlibat dalam proses pembelajaran sehingga penguasaan terhadap kompetensi yang akan dicapai seharusnya lebih besar. Salah satu cara yang paling efektif adalah mengajak mahasiswa melihat langsung ke lokasi (kunjungan studi) sesuai tema mata pelajaran yang pada saat itu dipelajarinya untuk bisa menambah wawasan dan pengetahuan mahasiswa terhadap objek tersebut. Dengan demikian, aktivitas itu diharapkan dapat meningkatkan kemampuan mahasiswa untuk bisa menguasai materi pelajaran yang dipelajarinya.

Tujuan dilaksanakannya field study ini agar terjadi distribusi informasi maupun pengalaman dari pihak yang sudah lebih mampu atau berkompeten kepada peserta kunjungan studi, sehingga kemampuan dan pola pikir peserta didik yang mengikuti kunjungan studi lebih meningkat. Ini dapat dilihat dari peningkatan kompetensi peserta didik dari sebelum mengikuti kunjungan studi dibandingkan dengan setelah mengikuti kunjungan studi. Namun kegiatan belajar 
dengan field study ini tidak akan dapat terlaksana jika tidak didukung oleh semua pihak terkait.

Artikel ini bertujuan mengetahui adakah manfaat yang diperoleh dari hasil field study terhadap peningkatan kompetensi mahasiswa yang mengikutinya, terutama mahasiswa pada Fakultas Ekonomi Universitas Samudra.

\section{Field Study}

Menurut Bevan dan Sharon (2009), field study atau studi lapangan adalah metode pembelajaran melalui pengumpulan data secara langsung dengan pengamatan, wawancara, mencatat, atau mengajukan pertanyaan-pertanyaan. Pada saat proses berlangsung, pembelajar berada langsung di lapangan. Field study dirancang memberikan peserta didik kesempatan untuk memeriksa permasalahannya di lapangan, mengevaluasi manfaat dari ide-ide yang disajikan dalam kelas, dan untuk mendidik siswa dalam melakukan observasi serta penyelidikan naturalistik. Peserta didik berpartisipasi dalam kegiatan yang sedang berlangsung. Studi lapangan juga menawarkan siswa terkait kesempatan proyek pengumpulan data, teoripengujian, dan intervensi sosial.

Istilah lain yang setara dengan field study adalah karyawisata (field trip). Menurut Suprijanto (2009), karyawisata biasanya berhubungan dengan kegiatan mengunjungi beberapa tempat menarik serta membutuhkan waktu lebih lama dibandingkan kunjungan lapangan atau field study. Karyawisata adalah suatu proses pembelajaran yang di lakukan dengan jalan mengajak peserta didik keluar kelas untuk dapat memperlihatkan hal-hal atau peristiwa yang ada hubungannya dengan bahan pelajaran. Karyawisata juga merupakan suatu metode pembelajaran dengan cara perjalanan atau pesiar yang dilakukan untuk memperoleh pengalaman belajar, terutama pengalaman langsung dan merupakan bagian integral dari kurikulum sekolah.

Berdasarkan beberapa pengertian itu, maka dapat disimpulkan bahwa field study atau fieldtrip atau outdoor learning adalah suatu kegiatan pembelajaran yang dilakukan dengan mengunjungi tempat-tempat tertentu yang telah ditentukan sebelumnya. Kegiatan yang dilakukan yaitu melakukan pengamatan dengan tujuan memberikan pengalaman secara langsung.

Tujuan dilaksanakan field study antara lain agar peserta didik memperoleh pengalaman langsung dari obyek yang dilihatnya dan dapat turut menghayati tugas pekerjaan milik seseorang serta dapat bertanya jawab mungkin. Dengan jalan demikian, mereka mampu memecahkan persoalan yang dihadapinya dalam pelajaran, ataupun pengetahuan umum. Selain itu, peserta didik akan dapat melihat, mendengar, meneliti dan mencoba apa yang dihadapinya, agar nantinya dapat mengambil kesimpulan, dan sekaligus dalam waktu yang sama ia bisa mempelajari beberapa mata pelajaran.

Field study menerapkan prinsip-prinsip pengajaran modern yang mana memanfaatkan lingkungan nyata dalam pengajaran. Peserta didik dapat berpartisipasi dalam berbagai kegiatan yang dilakukan oleh para instruktur maupun guru pembimbing serta mengalami dan menghayati langsung apa yang dilakukan, memperoleh bermacam-macam pengetahuan dan pengalaman yang terintegrasi dan terpadu, serta membuat materi yang dipelajari di sekolah menjadi lebih relevan dengan kenyataan dan kebutuhan yang ada di masyarakat, serta tentunya juga dapat lebih merangsang kreativitas peserta didik.

Beberapa manfaat dari field study menurut Suprijanto (2009: 132-133) adalah:

1. Memberikan kesempatan untuk dapat mengumpulkan pengalaman dan informasi baru;

2. Benda-benda dapat diamati dalam bentuk aslinya;

3. Tiga dimensi, warna alami, dan gerakangerakan dapat diamati;

4. Minat dan ketelitian pengamatan anggota dapat ditumbuhkan;

5. Kesempatan dapat diberikan kepada peserta untuk belajar sambil bekerja;

6. Prosedur dapat diamati, yang nantinya dapat diterapkan oleh peserta; serta,

7. Memberi kesempatan kepada peserta untuk menggabungkan pelajaran disekolah dengan yang didapat di lingkungan. 


\section{Pengembangan Sumberdaya Manusia}

Pengembangan (development) adalah penyiapan individu untuk memikul tanggung jawab yang berbeda atau yang lebih tinggi di dalam suatu organisasi atau institusi (Simamora, 2006). Pengembangan biasanya terkait dengan peningkatan kemampuan intelektual atau emosional yang diperlukan untuk menuaikan pekerjaan yang lebih baik. Pengembangan berpijak pada fakta bahwa seorang manusia akan selalu membutuhkan pengetahuan, keahlian, dan kemampuan yang berkembang supaya dapat melakukan sesuatu dengan baik dalam suksesi posisi yang dijalani selama karirnya.

Pengembangan SDM dirasa semakin penting manfaatnya karena tuntutan pekerjaan atau jabatan, sebagai akibat kemajuan teknologi dan semakin ketatnya persaingan di antara perusahaan sejenis. Setiap SDM dituntut agar dapat bekerja efektif dan efisien agar kualitas dan kuantitas pekerjaannya menjadi lebih baik, sehingga daya saing perusahaan semakin besar.Pengembangan ini dilakukan untuk tujuan non karier maupun karier melalui latihan dan pendidikan.

Mahasiswa selaku sumber daya manusia yang unggul dipersiapkan sejak dini untuk dapat bersaing dalam era kemajuan teknologi saat ini. Pengembangan SDM tersebut dalam program pengembangan harus dituangkan sasaran, kebijaksanaan prosedur, anggaran, peserta, kurikulum, dan waktu pelaksanaan nya (Simamora, 2006; Fuad et al., 2017). Program pengembangan harus berprinsipkan pada peningkatan efektivitas dan efisiensi kerja masing-masing.

Program pengembangan ini baiknya diinformasikan secara terbuka kepada semua mahasiswa supaya mereka mempersiapkan dirinya masing-masing. Dalam hal ini, bentuk pengembangan SDM dikelompokkan atas dua, yaitu; (1) pengembangan yang bersifat informal, serta (2) pengembangan secara formal (Hasibuan, 2008). Pengembangan secara informal yaitu mahasiswa atas keinginan dan usaha sendiri melatih dan mengembangkan dirinya dengan mempelajari buku-buku literatur yang berhubungan dengan pelajaran ataupun tugasnya. Pengembangan secara informal menunjukkan bahwa mahasiswa tersebut berkeinginan keras untuk maju dengan cara meningkatkan kemampuan kerjanya. Hal ini bermanfaat bagi organisasi karena produktivitas semakin besar, di samping efisiensi dan semakin baik.

Pengembangan secara formal yaitu mahasiswa ditugaskan untuk mengikuti pendidikan atau latihan, baik yang dilakukan oleh tenaga pendidik atau yang dilaksanakan oleh lembaga-lembaga pendidikan atau pelatihan. Pengembangan secara formal dilakukan di organisasi karena tuntutan pekerjaan saat ini ataupun untuk masa datang, sifatnya non-karier atau peningkatan karier seseorang. Pelatihan dan pengembangan (training and development) diakui memang memerlukan biaya yang cukup besar, namun investasi di bidang manusia tersebut (human investment) pada akhirnya diekspektasikan akan dapat menyumbangkan produktivitas yang sangat tinggi bagi organisasi. Untuk itu, organisasi tentunya akan memetik laba yang berlipat ganda di waktu yang akan datang.

Program pengembangan SDM hendaknya disusun secara cermat dan didasarkan kepada metode-metode ilmiah serta berpedoman kepada keterampilan yang dibutuhkan saat ini maupun untuk masa depan. Pengembangan harus memiliki tujuan untuk meningkatkan kemampuan teknis, teoritis, konseptual, dan moral mahasiswa supaya produktivitas kerjanya baik dan mencapai hasil yang optimal.

Tujuan pengembangan SDM adalah untuk memperbaiki efektivitas kerja dalam mencapai hasil-hasil kerja yang telah ditetapkan. Perbaikan efektivitas kerja dapat dilakukan melalui berbagai upaya yang ditujukan untuk memperbaiki pengetahuan, keterampilan maupun sikap itu sendiri atas tugas-tugasnya (Heidjrachman \& Husnan, 2004).

Pengembangan SDM bertujuan dan bermanfaat bagi perusahaan, karyawan, konsumen, atau masyarakat yang mana mengkonsumsi barang atau jasa yang dihasilkan perusahaan. Menurut Tohardi (2008), tujuan pengembangan adalah: 
1. Produktivitas. Dengan pengembangan, produktivitas kerja karyawan akan meningkat, kualitas dan kuantitas produksi semakin baik, karena technical skill, human skill dan managerial skill karyawan akan semakin baik.

2. Efisiensi. Pengembangan karyawan untuk meningkatkan efisiensi sumber daya manusia, perencanaan waktu, pengelolaan bahan baku dan mengurangi ausnya mesin-mesin, pemborosan berkurang, biaya produksi relatif kecil sehingga daya saing perusahaan semakin kecil.

3. Kerusakan. Pengembangan karyawan bertujuan untuk mengurangi kerusakan barang, produksi dan mesin-mesin karena karyawan semakin ahli dan terampil dalam melaksanakan pekerjaannya.

4. Kecelakaan. Pengembangan bertujuan untuk mengurangi tingkat kecelakaan karyawan, sehingga jumlah biaya pengobatan yang dikeluarkan perusahaan berkurang.

5. Pelayanan. Pengembangan bertujuan untuk meningkatkan pelayanan yang lebih baik dari karyawan kepada konsumen perusahaan, karena pemberian pelayanan yang lebih baik merupakan daya penarik yang sangat penting bagi rekanan-rekanan perusahaan bersangkutan.

6. Moral. Dengan pengembangan, moral karyawan akan lebih baik karena keahlian dan keterampilannya sesuai dengan pekerjaannya, sehingga mereka antusias untuk dapat menyelesaikan pekerjaannya dengan baik.

7. Karier. Melalui proses pengembangan, kesempatan untuk meningkatkan karier karyawan semakin besar, karena keahlian, keterampilan dan prestasi kerjanya lebih baik. Promosi biasanya didasarkan kepada keahlian dan prestasi kerja seseorang.

8. Konseptual. Melalui pengembangan, manajer akan semakin cakap dan cepat dalam mengambil keputusan yang lebih baik, karena technical skill, human skill dan managerial skill-nya lebih baik.

9. Kepemimpinan. Dengan pengembangan, kepemimpinan seorang manajer akan lebih baik, human relations-nya lebih luas, motivasi lebih terarah, sehingga pembinaan kerja sama vertikal dan horizontal semakin harmonis.

10. Balas Jasa. Dengan pengembangan, balas jasa (gaji, upah, intensif dan benefit) karyawan akan meningkat karena prestasi kerja mereka semakin besar.

11. Konsumen. Pengembangan karyawan akan memberikan manfaat yang lebih baik bagi masyarakat konsumen karena mereka akan memperoleh barang atau pelayanan yang lebih bermutu.

Sumber daya manusia (SDM) merupakan salah satu faktor penting atau utama dalam pembangunan. Secara makro, faktor-faktor masukan pembangunan, seperti sumber daya alam, material dan finansial tidak akan memberi manfaat secara optimal untuk perbaikan kesejahteraan rakyat bila tidak didukung memadainya ketersediaan faktor SDM, baik secara kualitas maupun kuantitas. Pelajaran yang dapat dipetik dari berbagai negara maju adalah bahwa kemajuan yang dicapai oleh bangsa-bangsa di negaranegara tersebut didukung oleh SDM yang berkualitas.

Pengembangan SDM melalui aspek pendidikan difokuskan kepada peningkatan ketahanan dan kompetensi setiap individu. Peningkatan ketahanan dan kompetensi ini di antaranya dilaksanakan melalui pendidikan. Bila dikaitkan dengan pengembangan SDM dalam rangka meningkatkan kemampuan maupun menyesuaikan diri, pendidikan juga dapat merupakan upaya meningkatkan derajat kompetensi dengan tujuan agar pesertanya adaptable terhadap berbagai perubahan dan tantangan yang dihadapi. Selain itu, proses pendidikan yang diselenggarakan seharusnya juga memberi bekal-bekal kemampuan dan keterampilan untuk melakukan suatu jenis pekerjaan tertentu yang dibutuhkan agar bisa berpartisipasi baik di dalam pembangunan (Boediono, 1992).

Jalur pendidikan merupakan tulang punggung pengembangan SDM yang dimulai dari tingkat dasar sampai perguruan tinggi. Arah pembangunan SDM ditujukan pada pengembangan kualitas SDM baik secara 
komprehensif meliputi aspek kepribadian dan sikap mental, penguasaan ilmu dan teknologi, maupun profesionalisme dan kompetensi yang kesemuanya dijiwai oleh nilai-nilai religius sesuai dengan agamanya. Dengan kata lain, pengembangan SDM meliputi pengembangan kecerdasan akal (IQ), kecerdasan sosial (EQ) dan kecerdasan spiritual (SQ).

\section{Kompetensi}

Menurut Kamus Bahasa Indonesia yang dikutip oleh Uzer (2006), kompetensi berarti kewenangan (kekuasaan) untuk menentukan atau memutuskan sesuatu hal. Pengertian dasar dari kompetensi (competency) yakni kemampuan atau kecakapan. Uzer (2006) juga menyatakan bahwa kompetensi adalah perilaku yang rasional untuk mencapai tujuan yang dipersyaratkan sesuai yang diharapkan. Kompetensi adalah pengetahuan, ketrampilan, dan nilai-nilai dasar yang direfleksikan dalam kebiasaan berpikir dan bertindak (Depdiknas, 2002).

Selanjutnya menurut Dinda (2017), kompetensi adalah kemampuan dalam kerja dengan mengintegrasikan antara pengetahuan, keterampilan, kemampuan serta nilai-nilai pribadi berdasarkan pengalaman dan pembelajaran dalam rangka pelaksanaan tugasnya secara professional, efektif dan efisien. Dari definisi ini diperoleh tiga kriteria kompetensi, yaitu:

1. Mampu melaksanakan keseluruhan tugastugas dari suatu pekerjaan, lebih dari pada memiliki ketrampilan atau tugas-tugas pekerjaan yang spesifik.

2. Sesuai dengan standar yang diharapkan dalam pekerjaan.

3. Dalam pekerjaan lingkungan pekerjaan nyata yang memberi tekanan dan berkaitan dengan seluruh pekerjaan dan variasivariasi pekerjaan yang sebenarnya.

Kompetensi merupakan karakteristik dasar yang terdiri dari ketrampilan, pengetahuan, serta atribut personal lainnya yang mampu membedakan apakah seseorang itu dinilai perform dan tidak perform. Spence dan Spencer (1993) membuat klasifikasi kompetensi menjadi karakteristik dasar, hubungan sebab akibat dan acuan kriteria sebagai berikut:

1. Karakteristik dasar adalah kompetensi sebagai bagian dari kepribadian individu dan dapat memprediksikan perilaku dalam situasi dan tugas, yaitu:

a. Motif sebagai dorongan dari diri seseorang secara konsisten untuk melakukan suatu tindakan;

b. Sifat/watak yaitu karakteristik fisik dan respon yang konsisten terhadap situasi atau informasi tertentu;

c. Konsep diri yaitu nilai-nilai sikap atau citra diri yang dimiliki individu;

d. Pengetahuan yaitu informasi yang dimiliki seseorang untuk bidang tertentu; dan,

e. Ketrampilan yaitu kemampuan untuk melaksanakan tugas secara fisik atau mental.

2. Hubungan sebab akibat adalahkompetensi yang menyebabkan dan memprediksi tindakan perilaku yang pada akhirnya dapat memprediksi hasil kinerja kerja. Kompetensi motif, sifat/watak dan konsep diri dapat memprediksi tindakan perilaku, yang pada akhirnya dapat memprediksi hasil kinerja.

3. Acuan kriteria adalah kompetensi paling kritis yang dapat membedakan kompetensi dengan kinerja tinggi atau rata-rata (Harun, 2007).

Kompetensi menurut Hall dan Jones adalah pernyataan yang menggambarkan penampilan suatu kemampuan tertentu secara bulat yang merupakan perpaduan antara pengetahuan dan kemampuan yang dapat diamati dan diukur.

Menurut Hamzah (2007), domain psikomotor mencakup tujuan yang berkaitan dengan ketrampilan (skill) yang bersifat manual atau motorik. Sebagai kedua domain yang lain, domain ini juga mempunyai berbagai tingkatan. Urutan tingkatan dari yang paling sederhana sampai ke yang paling kompleks (tertinggi) adalah:

a. Persepsi, berkenaan dengan penguasaan indra dalam melakukan kegiatan seperti 
mengenal kerusakan mesin dari suaranya yang sumbang, atau menghubungkan suara musik dengan tarian tertentu.

b. Kesiapan, berkenaan dengan kegiatan melakukan sesuatu kegiatan (set) termasuk didalamnya mental set (kesiapan mental), physikcal set (kesiapan fisik) atau emosional set (kesiapan perasan) untuk melakukan suatu tindakan.

c. Gerakan terbimbing, seperti meniru (imitasi) atau mengikuti, mengulangi, perbuatan yang diperintahkan ataupun ditunjukkan oleh orang lain, melakukan kegiatan coba-coba (trial and error).

d. Gerakan yang terbiasa, berkenaan dengan kegiatan melakukan sesuatu kegiatan (set) termasuk didalamnya mencakup mental set (kesiapan mental), physical set (kesiapan fisik) ataupun emosional set (kesiapan perasaan untuk melakukan suatu tindakan.

e. Gerakan kompleks, adalah penampilan gerakan motorik dengan keterampilan penuh kemahiran yang dipertunjukkan biasanya cepat dengan hasil yang baik, namun menggunakan sedikit tenaga. Seperti ketrampilan menyetir kendaraan bermotor.

f. Penyusunan Pola Gerak atau adaptasi, berkenaan dengan ketrampilan yang sudah berkembang pada diri individu sehingga yang bersangkutan mampu memodifikasi (membuat perubahan) pada pola gerakan sesuai dengan situasi dan kondisi tertentu. Hal ini terkait seperti pada orang bermain tenis, pola-pola gerakan disesuaikan dengan kebutuhan mematahkan permainan lawan.

g. Kreatifitas, merujuk pada penciptaan pola gerakan baru untuk disesuaikan dengan situasi atau masalah tertentu. Biasanya hal ini dapat dilakukan oleh orang yang sudah mempunyai ketrampilan tinggi seperti menciptakan mode pakaian, komposisi musik, atau menciptakan tarian

\section{Preposisi}

Berdasarkan telaah pustaka yang telah dilakukan, dikemukakan preposisi terkait topik pembahasan ini bahwa field study memiliki manfaat yang baik dengan tujuan untuk meningkatkan kompetensi mahasiswa utama sesuai dengan bidang ilmu yang diambil dan lokasi atau objek kunjungan studi yang diambil.

\section{METODE PENELITIAN}

Dalam penelitian ini metode pengumpulan data yang digunakan adalah wawancara dan dokumentasi. Moleong (2008) menyatakan wawancara adalah percakapan dengan maksud tertentu yang dilakukan oleh dua pihak, yaitu pewawancara yang mengajukan pertanyaan dan terwawancara yang memberikan jawaban atas pertanyaan tersebut yang berkaitan dengan penelitian ini. Sebelum melakukan wawancara, penulis terlebih dahulu menyusun daftar pertanyaan yang akan diajukan kepada informan agar terstruktur sedemikian rupa.

Dokumentasi, di sisi lain, menurut Sugiyono (2012) adalah catatan peristiwa yang sudah berlalu. Dokumen yang digunakan peneliti yang bisa berupa rekaman wawancara mengenai manfaat field study yang telah dilakukan oleh mahasiswa terhadap peningkatan kompetensi.

Penentuan informan menggunakan teknik purposive sampling yang mempunyai arti dengan memilih subjek penelitian dan lokasi penelitian dengan tujuan untuk mempelajari atau memahami permasalahan pokok yang akan diteliti (Herdiansyah, 2009). Informan dalam penelitian ini adalah mahasiswa Fakultas Ekonomi Universitas Samudra yang sudah pernah mengikuti field study. Informan diambil menggunakan metode snowball sampling, dikarenakan fenomena yang diteliti dapat berkembang menjadi lebih dalam dan lebih luas dari yang ditentukan sebelumnya sehingga disesuaikan dengan kebutuhan data yang telah diperoleh. Metode tersebut digunakan agar diperoleh data yang akurat dan mendalam mengenai kondisi serta permasalahan yang ada.

\section{Metode Analisis Data}

Herdiansyah (2009) mengungkapkan proses analisis data dalam penelitian kualitatif sudah dimulai dan dilakukan sejak awal penelitian hingga penelitian selesai. Hal ini 
berarti setiap pelaksanaan proses pengambilan data, peneliti langsung melakukan analisis dari data tersebut seperti pemilahan tema dan kategorisasinya.

Dalam pembahasan ini, model analisis data interaktif menurut Miles dan Huberman digunakan. Model analisis data ini memiliki empat tahapan, yaitu tahap pertama berupa pengumpulan data, tahap kedua adalah reduksi data, tahap ketiga adalah display data, dan tahap keempat merupakan proses penarikan kesimpulan serta verifikasi data. Masing-masing tahapan tersebut dijelaskan sebagai berikut:

1. Pengumpulan data. Proses pengumpulan data pada penelitian kualitatif telah dilakukan sebelum penelitian, saat penelitian, dan pada akhir penelitian. Pada awal penelitian, peneliti melakukan studi pre-eliminary untuk membuktikan bahwa femomena yang akan diangkat dan diteliti benar-benar ada dan layak untuk diteliti. Pada saat melakukan penelitian, observasi, catatan lapangan, atau bahkan ketika berinteraksi dengan lingkungan sosial dan informan, merupakan proses pengumpulan data yang hasilnya data yang akan diolah. Setelah data mencukupi untuk proses analisis, kemudian dilakukan reduksi data.

2. Reduksi data. Inti dari reduksi data adalah proses penyeragaman dan penggabungan semua bentuk data yang diperoleh menjadi satu bentuk tulisan yang akan dianalisis. Hasil wawancara akan diubah menjadi bentuk kutipan wawancara.

3. Display data. Display data adalah proses pengolahan semua data berbentuk tulisan menjadi beberapa kategori sesuai dengan tema atau kelompok masing-masing dan biasanya disajikan dalam bentuk tabel, diagram, matriks, ataupun grafik. Terdapat tiga tahapan dalam display data, yaitu:

- Tahap kategori tema, merupakan proses pengelompokkan tema-tema yang telah disusun dalam tabel wawancara ke dalam suatu matriks kategorisasi. Tema dalam penelitian ini antara lain:

a) Kesan mahasiswa sebelum kunjungan studi. b) Kesan mahasiswa saat kunjungan studi berlangsung.

c) Kesan mahasiswa setelah mengikuti kunjungan studi.

d) Nilai tambah yang didapat sebelum dan setelah mengikuti kunjungan studi.

e) Apa alasan mahasiswa mau mengikuti kunjungan studi.

f) Hal positif atau negatif yang dirasakan untuk mengikuti kunjungan studi.

g) Saran mahasiswa terhadap kegiatan kunjungan studi.

h) Pendapat mahasiswa kunjungan studi itu sebaiknya bagaimana.Hal-hal apa saja yang diharapkan mahasiswa setelah mengikuti kunjungan studi.

- Tahapan selanjutnya adalah subkategori tema. Inti dari tahap ini adalah membagi tema-tema tersebut ke dalam subtema yang merupakan bagian dari tema yang lebih kecil dan sederhana.

- Tahapan akhir yaitu proses pengkodean. Inti dari tahap ini adalah memasukkan ataupun mencantumkan pernyataanpernyataan informan sesuai dengan kategori tema dan subkategori temanya ke dalam matriks kategori serta memberikan kode tertentu pada setiap pernyataan-pernyataan informan tersebut.

4. Kesimpulan/verifikasi. Setelah ketiga tahapan selesai, tahapan akhir adalah penarikan kesimpulan atau verifikasi. Kesimpulan dalam model Miles dan Huberman berisi semua uraian dari subkategori tema yang tercantum pada tabel kategorisasi dan pengkodean yang sudah terselesaikan disertai dengan kutipan wawancaranya.

\section{HASIL ANALISIS Manfaat Kunjungan Studi}

Berdasarkan deskripsi informan yang diperoleh dari hasil wawancara, diidentifikasi bahwa kunjungan studi memiliki manfaat yang positif bagi mahasiswa. Manfaatmanfaat tersebut seperti memberi kesempatan untuk memperoleh pengalaman dan informasi baru; benda-benda dapat diamati dalam 
bentuk aslinya; tiga dimensi, warna alami, dan gerakan-gerakan dapat diamati; minat dan ketelitian pengamatan anggota dapat ditumbuhkan; kesempatan dapat diberikan kepada peserta untuk belajar sambil bekerja; prosedur dapat diamati, yang nantinya dapat diterapkan oleh peserta; serta memberi kesempatan kepada para peserta untuk menggabungkan pelajaran di sekolah dengan yang diperoleh di lingkungan (Suprijanto, 2009). Seperti dinyatakan para informan:

"Ada informasi baru dirasakan, ada lah saya bisa tau sedikit banyak bagaimana struktur organisasi di perusahaan. Biasa belajar cuma di kampus aja tidak pernah keluar, jadi cuma materi-materi aja gitu. Kita tidak pernah keluar jadi sebenarnya kita harus melihat bagimana dunia kerja. Saya berharap di kampus kita ada magangnya. Itu yang terpenting. Setahu saya, di kampus kita hanya ada KPM-nya aja. Kalau manajemen seharusnya ada magangnya" (DA).

"Yang didapat dari kunjungan studi ini, manfaatnya jadi kita tau hasil pengolahan nya itu hasil itu impornya kemana. Udah itu, karena belum kunjungan studi, karena pingin tau biar ada pengalaman" (M).

"Saat kunjungan studi setelah berlangsung kebersamaan bersama teman-teman kekeluargaan di situ. Juga untuk di perusahaan itu kita tahu cara kerja perusahaan itu gimana, walaupun enggak secara langsung kita lihat operasionalnya setidaknya tau lah bagaimana prosesnya" (HS).

"Manfaat yang didapat setelah kunjungan studi saya sendiri, setidaknya saya tau disana ada (PT) Mopoly Raya. Sebelumnya tidak pernah tau. Disanakan perbatasan Langkat dan tidak pernah ke daerah sana, jadi ya taulah bagaimana bentuk mesin-mesin pengolahan kelapa sawit. Ada terlihat dikit masalahnya sebelumnya tidak pernah tau, tau pinginnya lebih detil lagi" (TS)

"Manfaatnya dengan lihat langsung ke sana, ke lapangan, walaupun gak 100\%, kita bilang dapat yang diinginkan. Tapi ada lah maksudnya gambaran dan lihat mata kepala langsung ke lapangan ya berbeda dengan cuma lihat di kelas gitu kan" (II).

Terkait informasi yang diterima dari para informan seperti demikian, maka dapat dianalisis bahwasanya peserta kunjungan studi memang mendapatkan manfaat yang sangat baik berupa informasi-informasi terbaru dan membuka wawasan dengan materi-materi terbarukan.

Di sisi lain, dengan adanya field study ini, pengalaman baru berupa pengenalan manajemen maupun proses produksi di dalam perusahaan bisa dilihat langsung, sehingga informasi yang diperoleh bisa disesuaikan dengan materi yang diperoleh di bangku perkuliahan.

\section{Peningkatan Kompetensi}

Pengertian dasar dari kompetensi (competency) yakni kemampuan atau kecakapan. Kompetensi merupakan perilaku yang rasional untuk mencapai tujuan yang dipersyaratkan sesuai yang diharapkan (Uzer, 2006). Kompetensi merupakan pengetahuan, ketrampilan, dan nilai-nilai dasar yang direfleksikan dalam kebiasaan berpikir dan bertindak (Depdiknas, 2002). Seperti dinyatakan para informan:

"Ya saya merasa puas, Pak, dan lebih mengetahui pengalaman. Maksudnya kalau teori kan kita belum tentu tahu semua, Pak. Tapi kalau udah studi ke tempatnya, ke lapangan, kita lebih banyak tahu lah dari kunjungan studi kemaren, Pak. Kita jadi tambah pengalaman. Kita tambah wawasan. Kita mengetahui sesuatu gitu, Pak. Emang pingin kita sendiri karna kita kan niat, kan pulang belum tentu teori ini bisa sebelum kita tengok langsung, oh kayak ini cara kerja. Oh maksudnya, ada kesan pingin membandingkan bagaimana di kelas, bagaimana di lapangannya. Iya kan beda gitu, Pak. Kan sama teori bapak kan beda. Iya setelah kunjungan lah, Pak. Kesan kita yang maksudnya pas kita itu kan kita, oh 
berarti sistem kerja PT begini-begini, orang perusahaan begini, orang kerja bagian ini begini. Ya gitu, Pak" (RP).

"Emh, sebenarnya gini kunjungan studi itu kan perlu, Pak. Untuk kita praktek langsung teori apa yang udah kita pelajari itu, Pak. Jadi dengan adanya studi itu kita lebih memahami apa sih sebenarnya, karna kan biasa nya kan teori sama praktek itu berbeda" (II)

"Bagi saya, menambah ilmu ya menambah pengetahuan wawasan. Kalau bisa ya ada studi tour selanjutnya. Kalau bisa ya lebih jauh gitu kan. Ya ilmu pengetahuan tentang MSDM, tentang SIM, juga saya dapat. Disitukan dijelaskan semua tentang hubungan industrinya tentang informasi manajemennya kan dijelaskan sama GM-nya kan" (AN).

Terkait informasi yang diterima dari para informan seperti tersebut, maka dapat dianalisis bahwa peserta field study melihat adanya perbedaan antara teori yang didapat di bangku perkuliahan dengan kondisi di lapangan. Jadi pemahaman baru didapatkan baik dari sisi ilmu maupun praktek, dan peserta field study memiliki pemahaman berupa kemampuan (kecakapan) untuk dapat membandingkan ilmu yang didapat di bangku perkuliahan dengan kondisi di lapangan yang sebenarnya.

\section{Proposisi Penelitian}

Berdasarkan temuan penelitian berupa pernyataan-pernayataan dari para informan yang menunjukkan deskripsi manfaat field study bagi mahasiswa, maka bisa dirumuskan proposisi yang pertama sebagai berikut:

"Mahasiswa setelah mengikuti field study banyak mendapatkan manfaat yang positif, diantaranya informasiinformasi baru/terkini, bisa melihat langsung dunia kerja, bertambah pengalaman, dan dapat membandingkan teori yang didapat di dalam kelas dengan yang ada di lapangan".
Berdasarkan temuan penelitian berupa pernyataan-pernyataan dari para informan yang menunjukkan deskripsi peningkatan kompetensi mahasiswa, maka dapat dirumuskan proposisi yang kedua sebagai berikut:

"Kompetensi mahasiswa menjadi meningkat setelah mengikuti field study berupa bertambahnya pengetahuan dan wawasan tentang dunia kerja dan mahasiswa menjadi lebih kritis terhadap lingkungan disekitarnya".

\section{KESIMPULAN}

Berdasarkan hasil penelitian dan pembahasan dalam penelitian ini, maka beberapa kesimpulan dikemukakan sebagai berikut:

a. Field study merupakan salah satu sarana pembelajaran efektif untuk meningkatkan ilmu pengetahuan mahasiswa dengan berbagai manfaat yang bisa didapat oleh mahasiswa.

b. Untuk mampu meningkatkan kompetensi mahasiswa, field study merupakan sarana yang sangat mendukung karena mahasiswa bisa melihat langsung kejadian lapangan serta dapat membandingkan langsung teori yang didapat di dalam kelas dengan di lapangan.

c. Terdapat manfaat field study bagi peningkatan kompetensi mahasiswa pada Fakultas Ekonomi Universitas Samudra.

Berdasarkan kesimpulan, maka dapat direkomendasikan sebagai berikut:

a. Field study sebaiknya dilaksanakan rutin setiap semester untuk mata kuliah yang sesuai.

b. Pelaksanaan field study dikelola langsung oleh Dosen yang mengampu mata kuliah, dengan tetap berkoordinasi pada atasan langsung.

c. Pendanaan field study bisa dibebankan kepada anggaran Fakultas, sehingga tidak memberatkan pihak mahasiswa.

d. Keterlibatan mahasiswa dalam kunjungan studi harus lebih intensif. 


\section{DAFTAR PUSTAKA}

Arikunto, S. 2009. Dasar-Dasar Evaluasi Pendidikan. Edisi Revisi. Jakarta: Bumi Aksara.

Bevan, N. dan Sharon, T. 2009. www.usabilitybok.org/field-study.

Boediono. 1992. Teori Pertumbuhan Ekonomi. Yogyakarta: BPFE UGM.

Depdiknas. 2009. Pedoman Pengembangan Kurikulum untuk Pembelajaran CI. Jakarta: Direktorat Pembinaan Sekolah Luar Biasa.

Dinda, F. 2017. Pengaruh Karakteristik Pekerjaan dan Kompetensi Karyawan terhadap Kinerja Karyawan pada CV. Percetakan Fajar Mojokerto. Jurnal Samudra Ekonomi dan Bisnis. Vol. 8, No. 1, hal. 700-709.

Fuad, M., Nurbaya, S. dan Amirullah. 2017. Pengantar Bisnis. Yogyakarta: Penerbit Indomedia Pustaka.

Hamzah B., Uno. 2008. Perencanaan Pembelajaran. Jakarta: PT. Bumi Aksara.

Harun, R. 2007. Metode Penelitian Kualitatif untuk Pelatihan.

Bandung: Mandar Maju.

Hasibuan, M.S.P. 2008. Manajemen Sumber

Daya Manusia. Jakarta: PT. Bumi Aksara.

Heidjrachman dan Husnan, S. 2004. Manajemen Personalia. Cetakan Kesebelas. Yogyakarta: BPFE.

Herdiansyah, H. 2009. Metodologi Penelitian Kualitatif untuk IlmuIlmu Sosial. Jakarta: Salemba Humanika.
Moleong, L.J. 2008. Metodologi Penelitian Kualitatif. Edisi Revisi. Bandung: Rosda.

Mulyasa. E. 2006. Kurikulum Tingkat Satuan Pendidikan. Bandung: PT. Remaja Rosdakarya.

Muslich, M. 2009. Melaksanakan PTK (Penelitian Tindakan Kelas) itu Mudah. Jakarta: Bumi Aksara.

Riyanto,Y. 2010. Metodologi Penelitian Pendidikan. Surabaya: Penerbit SIC.

Sanjaya, W. 2009. Strategi Pembelajaran Berorientasi Standar Proses Pendidikan. Jakarta: Prenada.

Sardiman. 2009. Interaksi dan Motivasi Belajar. Jakarta: PT. RajaGrafindo Persada.

Simamora, H. 2006. Manajemen Sumber Daya Manusia. Edisi 2. Yogyakarta: STIE YKPN.

Sugiyanto. 2010. Model-model Pembelajaran Inovatif. Surakarta: Yuma Pustaka.

Sugiyono. 2010. Metode Penelitian Pendidikan. Bandung: Alfabeta.

Suprijanto. 2009. Pendidikan Orang Dewasa. Jakarta: Bumi Aksara.

Tohardi, A. 2002. Pemahaman Praktis Manajemen Sumber Daya Manusia. Bandung: Universitas Tanjung Pura.

Uzer, M.U. 2000. Menjadi Guru Profesional. Bandung: PT. Remaja Rosdakarya. 